\title{
A EVANGELIZAÇÃO FALADA E ESCRITA: NOTAS SOBRE ESCRITA E ORALIDADE ECLESIÁSTICA NO BRASIL DO SÉCULO XVIII
}

EVANGELIZATION VIA WRITTEN AND SPOKEN WORD: REMARKS ON ECCLESIASTIC WRITING AND SPEECH IN BRAZIL IN THE $18^{T H}$ CENTURY

Enviado em 7 de março de 2015

Resumo: Neste artigo, apresentam-se notas de pesquisa sobre os usos da escrita e da oralidade na evangelização desenvolvida pela Igreja Católica no Brasil do século XVIII. Mostra como clérigos utilizavam destas formas de linguagem tentando exercer controle sobre o mundo social. Demonstra algumas características dos usos da escrita pelos padres, como forma de exercer poder sobre as populações coloniais. Apresenta, sobre este aspecto, a utilização das certidões batismais pela Igreja que visava construir uma memória escrita e arquivística capaz de dar aos clérigos informações sobre seus fregueses, o que possibilitava acompanhar a trajetória de cada um dentro do catolicismo. A oralidade, por seu turno, era utilizada na evangelização no decorrer das missas que eram provavelmente acompanhadas pelas cerimônias batismais. Os padres assumiam papel de oradores e a evangelização pela palavra falada poderia tomar curso amplificado, uma vez que, a oralidade possuía maior difusão do que a escrita durante o período colonial.

Palavras-chave: Fontes paroquiais. Escrita. Oralidade.

Abstract: This article presents research notes on the usage of the written and spoken word in evangelization developed by the Catholic Church in Brazil in the $18^{\text {th }}$ century. The article shows how clergy used these modes of language in the attempt to exercise control over the larger social world. The article

\footnotetext{
1 Graduação em História, Licenciatura pela Universidade Federal do Rio Grande do Sul (UFRGS). Mestre em História pela UFRGS e Doutor em História Social pela Universidade Federal do Rio de Janeiro (UFRJ). Professor de Graduação e de Pós-Graduação vinculado ao Programa em História da UFRGS. Email: eduardosneumann@gmail.com

2 Graduação em História pelo Centro Universitário Franciscano - UNIFRA. Mestre em História pelo Programa de Pós-Graduação em História da Universidade Federal do Rio Grande do Sul - UFRGS. Doutorando do Programa de Pós-Graduação em História da Universidade do Vale dos Sinos UNISINOS.
} 
demonstrates characteristics of the usage of the written word by the Church as a method of exercising power over colonial populations, for example, in the use of baptismal certificates in order to construct a written and archival memory that would give clergy information about their parishioners. This made it possible to follow the trajectories of these parishioners within Catholicism. The spoken word was employed in evangelization during masses, which were probably followed by baptismal ceremonies. The priests played the role of orators and the importance of evangelization via the spoken word became amplified given that the spoken word was much more easily disseminated than written texts during the colonial period.

Keywords: Parish sources. Writing. Oral speech.

\section{INTRODUÇÃO}

No ano de 1703, a Igreja Católica deu início ao primeiro sínodo realizado no Brasil, com o propósito de regulamentar as diretrizes eclesiásticas, ajustadas a realidade colonial. O sínodo realizado no Arcebispado da Bahia foi encerrado em 1707, tendo todas as suas deliberações compiladas nos livros das Constituições Primeiras do Arcebispado da Bahia, publicadas em Lisboa no ano de 1719. Trata-se de cinco livros distribuídos do seguinte modo: o Livro Primeiro regulamenta a forma pela qual os clérigos deveriam realizar os sacramentos; o Livro Segundo trata da liturgia; o Livro Terceiro das leis e do direito eclesiástico; o Livro Quarto dos direitos e deveres dos clérigos; e o Livro Quinto das proibições impostas aos clérigos.

A base teórica dos livros das Constituições era estabelecida nas prerrogativas do Concílio de Trento (1525-1563), portanto, as diretrizes eclesiásticas do sínodo baiano obedeciam, em linhas gerais, os preceitos da Contra Reforma religiosa. A partir da formalização das leis eclesiásticas no Brasil, as quais se converteram em leis escritas, foi possível à Igreja arquitetar de forma mais acabada o exercício de seu poder no mundo colonial atlântico e, neste sentido, o uso tanto da palavra falada quanto da palavra escrita teve papel fundamental.

Os registros vitais, certidões de batismo, crisma, matrimônio e óbito, por exemplo, possibilitam à Igreja acompanhar a vida dos seus fregueses nas diversas paróquias do Brasil no período colonial e, concomitantemente, exercer algum tipo de controle sobre a vida social. O processo escriturário destes registros, sobretudo o do batizado, constituía à Igreja não só a participação da vida religiosa, como também na interferência e organização da sociedade, tarefa que passava necessariamente pelo processo escriturário. 
Assim sendo, este artigo apresenta algumas notas sobre os usos da oralidade e da escrita praticadas pela Igreja Católica no exercício de seu poder sobre a vida social. O foco de análise centra-se no ato do batismo e sua consequente escrituração, ou seja, tenta demonstrar como a Igreja se utilizou da escrita e da oralidade como formas de regular a vida dos mais diversos agentes sociais como índios, luso-brasileiros, mestiços, escravos e libertos. Através do modo escriturário utilizado pela Igreja, na composição das certidões batismais, se pode notar a forma pela qual a Igreja organizava e interpretava o mundo social. Tomaremos como exemplo os batizados realizados no Acampamento do Rio Pardo.

\section{USOS DA ESCRITA E DA ORALIDADE ECLESIÁSTICA}

Em 1752, militares portugueses estacionados à margem direita do rio Jacuí, no encontro com seu afluente, o rio Pardo, erigiram uma fortaleza a qual recebeu o nome de Jesus, Maria, José. Sua função, além de guarnecer a posição portuguesa, era de servir como paiol das tropas lusitanas que partiram à região das Missões Orientais, localizadas nas proximidades do rio Uruguai, entregues à Coroa de Portugal pela Espanha, seguindo os termos fixados pelo Tratado de Madrid (1750). Portugal cedeu a Colônia do Sacramento para assumir o controle da região missioneira pertencente à Coroa Espanhola.

No ano seguinte à construção da fortaleza, dentro de seus limites foi construída uma capela a qual recebeu a mesma invocação da fortificação; Jesus, Maria, José. Como demonstram os registros escritos remanescentes daquele período, os padres se referiam ao local como Acampamento de Rio Pardo. ${ }^{3}$ Os primeiros batizados realizados na capela da fortaleza datam de fevereiro de 1755 . Pelos registros batismais assentados no Livro I (1755-1762), nota-se forte presença de açorianos desde os anos iniciais. Ocorreram poucos batizados de escravos.

A partir de 1757, foram realizados os primeiros batizados de índios guaranis. Estes batizados correspondem provavelmente aqueles que pertenciam aos filhos de índios missioneiros que se reuniram em aldeamentos ao redor da fortaleza. Em 1762, por ordem do governador Marcelino José de Figueiredo, os índios foram agrupados em um único aldeamento, conhecido como Aldeia de São Nicolau do Rio Pardo, sendo extinto apenas na década de 1860 , durando exatamente um século. ${ }^{4}$

\footnotetext{
${ }^{3}$ Referência encontrada nos termos de abertura dos livros de batismo.

4 Sobre o aldeamento de Rio Pardo ver: MELO, Karina Moreira Ribeiro da Silva e. A aldeia de São Nicolau do Rio Pardo: histórias vividas por índios guaranis (séculos XVIII-XIX). 2011. 167 f. Dissertação (Mestrado em História) - Universidade Federal do Rio Grande do Sul, Porto Alegre,2011.
} 
Inicialmente, nota-se que o Acampamento de Rio Pardo foi constituído demograficamente por população mista. Esta diversidade humana se fez representar nos primeiros anos das migrações ao nascente Acampamento, como se pode perceber pelos números gerais dos batizados. Ao total, foram contabilizadas 538 cerimônias batismais as quais podem ser divididas da seguinte forma: 283 (55\%) registros para índios, 203 (39\%) para crianças brancas e 31 (6\%) de escravos. ${ }^{5}$

Os percentuais indicam que os índios guaranis, provavelmente foram maioria demográfica no Acampamento, seguidos de um contingente populacional de pessoas brancas. O número de escravos, se comparado aos índios e aos brancos é quase incipiente, porém, cabe ressaltar que a tendência geral é o aumento do número de escravos, devido à aquisição via tráfico atlântico ao longo do tempo. Seguindo as datas destes batizados, podemos notar que a frequência das cerimônias batismais foi semanal. Houve alguns lapsos em alguns meses que, no entanto, não representou nenhuma quebra drástica na regularidade do sacramento.

Os registros de batismo, entretanto, são bem conhecidos pelos historiadores e utilizados nas pesquisas sob diversas perspectivas analíticas. No entanto, pouco ou nenhuma atenção tem se prestado a produção escrita destes registros. Do mesmo modo, sua função, seu uso e seu significado à administração eclesiástica não receberam qualquer atenção da historiografia. Segundo o historiador Antonio Castillo Gómez (1998, p. 346), "la escritura comporta una racionalidad: pensar, representar y administrar el mundo de un modo distinto al que opera las sociedades inscritas en el estadio de la oralidad primaria".

Podemos sugerir que a escrita ajudou a Igreja a racionalizar e organizar suas atividades, o exercício de seu poder e seu controle sobre o mundo social. As Constituições do Arcebispado da Bahia serviam como guia metodológico e escriturário para todas as intervenções da Igreja junto às populações da chamada América Portuguesa. As características mais gerais destes livros nos remetem para o que Castillo Gómez (1998, p. 348) chamou de memória administrativa. Operando a partir de uma memória do sínodo baiano, iniciado em 1703, a qual se converteu nos livros das Constituições, a Igreja ordenava que em cada paróquia houvesse uma cópia de tais livros, fato que nem sempre se consumou em realidade. ${ }^{6}$

\footnotetext{
${ }^{5}$ ACMPOA. Livros de Batismo. Rio Pardo, 1755-1762.

6 O visitador Agostinho José Mendes dos Reis, em 1790, fez várias reclamações quanto ao trabalho pastoral do pároco Manuel Marques de Sampaio. Entre as várias ordenações dadas pelo visitador, há um pedido expresso para que mandasse comprar o livro das Constituições Primeiras do Arcebispado da Bahia. (ACMPOA. Rio Pardo. Capítulos de Visitações, p. 7).
} 
Contudo, os indícios apontam que através dos livros das Constituições a Igreja tentou organizar sua administração em todo o território do Brasil no período colonial. O sentido de sua expansão por vastas regiões compostas por populações etnicamente diversificadas era de garantir a presença da fé católica. Nas palavras de Dom Sebastião Da Vide $(1707$, p. 2) as Constituições serviam para "direção dos costumes, extirpação dos vícios, e abusos, moderação dos crimes, e reta administração da Justiça" [...].Como demonstrou Fabio Kühn (1996), o Arcebispado do Rio de Janeiro, a partir da segunda metade do século XVIII, iniciou um projeto reformador o qual visava regular os comportamentos sociais em torno da vida religiosa. ${ }^{7}$

Garantir a realização dos sacramentos, neste sentido, consistia na atividade eclesiástica mais elementar na consumação deste projeto. Por tal razão, o sínodo baiano organizou um livro inteiro regulamentando o modo pelo qual os clérigos deveriam proceder com os sacramentos (Livro Segundo das Constituições). Pelos cânones da Igreja Católica, o primeiro dos sacramentos, instituído por Jesus Cristo, seria o batismo. Este ritual tinha como inspiração, pelas leis da Igreja o Rituale Romanum, livro no qual se reuniu todas as formas de se proceder como ritos católicos.

Pelas Constituições todos os sacramentos, para terem validade, enquanto ato ritual deveriam possuir matéria, forma e ministro. No caso do batismo, a matéria era água, a forma eram as palavras pronunciadas em latim "ego te baptizo in nomine patris et filii et spiritus sancti" (Eu te batizo em nome do pai do filho e do espírito santo). 0 ministro do batismo deveria ser obrigatoriamente um padre encomendado às paróquias por ordem dos Arcebispados. Na falta deles, por ventura, se admitia qualquer outra pessoa mesmo sendo um infiel ou uma mulher. (DA VIDE, 1707, Título $X X, \S 33)$.

Após a ablução, os santos óleos e a pronúncia da forma, segundo as instruções das Constituições, os padres deveriam retirar a criança da pia batismal, entregando-a aos padrinhos escolhidos pelos pais. Naquele momento, padrinhos e afiliados contraiam parentesco transcendental, sendo os padrinhos, aos olhos da Igreja, os pais espirituais dos batizandos. Ficava estipulado, também pelo sínodo baiano de 1707, que os padrinhos seriam dois, um homem e uma mulher e teriam a obrigação de ensinar a doutrina cristã e os "bons costumes" aos seus afilhados.

Mas o cerimonial, mesmo sendo realizado de acordo com o ritual romano, por si só não se legitimava. Era necessária obrigatória a escrituração do ritual através da certidão de batismo. Segundo as determinações do sínodo baiano o registro escrito do

\footnotetext{
7 Para maiores conhecimentos ver: KÜHN, Fabio. O projeto reformador da Diocese do Rio de Janeiro: as visitas pastorais no Rio Grande de São Pedro (1780-1815). 1996. 176 f. Dissertação (Mestrado em História) - Universidade Federal do Rio Grande do Sul, Porto Alegre, 1996.
} 
batismo servia como comprovação do cerimonial e do parentesco ritual contraído no sacramento entre a criança e seus padrinhos. O batismo, contudo, poderia ter significados cognitivos diferentes daquele instituído pela Igreja Católica.

Do ponto de vista eclesiástico, o sacramento servia para retirar o pecado original, garantindo a salvação da alma e a entrada no paraíso após a morte. Com relação ao direito eclesiástico, o batismo também era pré-requisito para os demais sacramentos, como a crisma e o matrimônio. Uma vez registrada a cerimônia do batismo, nos livros específicos para este fim, o assento batismal poderia servir como um documento escrito comprobatório pelos quais seria possível aos religiosos atestarem suas obrigações pastorais.

\section{SACRAMENTOS ECLESIÁSTICOS E MEMÓRIA ESCRITA}

Em boa medida o registro escrito servia como prova de que os padres realizavam o sacramento do batismo efetivamente. Aos que procuravam aquele sacramento, o registro escrito também servia como comprovante de suas "obrigações" católicas. Aos que iriam casar via matrimônio, por exemplo, era exigido que fossem batizados e, se não fossem, contariam com o impedimento ao matrimônio em função de não serem batizados. Até mesmo aos escravos, na situação de libertação na pia batismal, o registro servia como comprovação de seu estado social de forro.

Embora este quadro pareça caótico e diversificado, há em comum, em todas estas situações, a tentativa de se construir uma memória através do escrito, fenômeno que foi comum na modernidade. Para Fernando Bouza (1992), a construção da memória escrita se deu devido à incapacidade dos homens em transformar todo o passado em presente e, consequentemente, a partir do presente, sem memória, não poderia se organizar em relação ao futuro. A escrita estava a serviço da catequese, pois o mundo letrado pautou o trabalho de conversão e de controle administrativo. Nesse aspecto, a certidão de batismo, cumpria a função de imortalizar o ritual, a partir de uma memória escrita.

Os registros de batizados, conforme as exigências do sínodo baiano, deveriam estar assentados nos livros específicos e devidamente identificados com um termo de abertura geralmente prescrito "Este Livro a de servir para nele se lançarem os batizados dos (brancos, livres, cativos, etc.)". A escritura do termo era feita, em regra, pelos vigários ou visitadores e se encontra em todos os livros de batizados, matrimônios, crisma, óbito, etc. Os livros, por seu turno, deveriam ser encadernados, enumerados de página em página e, ao fim de cada certidão, deveria constar a assinatura do padre que redigiu a certidão. 
Os livros deveriam ser trancados em arcas ou em caixões das igrejas devidamente chaveados para evitar qualquer tipo de fraude. Procedimentos que implicaram na necessidade de estabelecer arquivos, locais para armazenar tais informações. A memória das monarquias ibéricas estava depositada nesses locais, que guardavam os papéis e documentos comprobatórios. Tais medidas possibilitavam aos religiosos a conservação dessas informações que poderiam ser usadas sempre que necessário. Não só em relação às cerimônias de batizado, assim como em relação aos matrimônios, às mortes, às ordens pastorais, às visitações dos clérigos que fiscalizavam o trabalho eclesiástico junto às paróquias: em relação a todos estes acontecimentos, foram escritos diversos volumes de livros para registrar cada acontecimento ligado à administração eclesiástica, com o propósito de se preservar a memória.

Os sacramentos assentados em livros e seu consequente acúmulo arquivístico possibilitava à Igreja elaborar estratégias de controle social a partir do confinamento da memória escrita em seus arquivos. Conforme aponta Castillo Gómez (1998), o uso da escrita favorecia à Igreja exercer seu poder, acompanhando a vida social, desde o nascimento até a morte. Os batizados comprovariam a entrada ao catolicismo, além de gerar uma memória em relação a sua filiação carnal (genitores) e espiritual (padrinhos), da sua condição social (índio, pardo, preto, branco, etc.), livre ou escravo.

O matrimônio, por exemplo, pelas Constituições tinha como pré-requisito básico a condição dos contraentes serem batizados e possuírem idade mínima; homem 14 e mulher 12 anos, além de não serem casados por matrimônio em outra paróquia (DA VIDE, 1707, Título LXIV, § 267).A certidão de matrimônio poderia servir como comprovação da união oficial entre homens e mulheres, mas também poderia impedir que os agentes sociais, por ventura, casassem novamente por via do matrimônio, o que era considerado crime pelas leis eclesiásticas. A construção da memória em torno do matrimônio possibilitava à Igreja coordenar as formas de casamento que, na visão eclesiástica, apenas era aceitável via matrimônio.

Um exemplo da importância do batismo em relação ao matrimônio pode ser vista na dispensa dada aos índios em duas paróquias do Rio Grande de São Pedro. Em 1764, o padre Mateus Pereira da Silva, foi ordenado a fazer os matrimônios dos índios guaranis "vindos das Missões e de outras partes", para se casar com "pardos e os naturais da terra", a partir do segundo grau de parentesco consanguíneo, verificando, porém se eram "batizados e se tinham a idade mínima". ${ }^{8}$ As exigências, contudo eram de não serem casados em outras freguesias, o que poderia ser verificado mediante aos processos de banho, o batismo e a idade mínima, já referida no parágrafo anterior.

${ }^{8}$ ACMPOA. Rio Pardo. Pastorais. Livro I, p. 7v. 
A mesma ordem foi dada ao vigário da freguesia de Porto Alegre, em 1797, para dispensar os índios do impedimento à consanguinidade a partir do segundo grau de parentesco, sob a condição do batismo e da idade mínima necessária. ${ }^{9}$ Podemos compreender de imediato que as certidões comprobatórias dos sacramentos possuíam uma função arquivística à Igreja. Do mesmo modo, nas certidões de óbito, como determinava o modelo escriturário das Constituições baianas, ficava registrado se o defunto havia recebido todos os sacramentos ou parte deles. Caso não houvessem recebido todos, os padres deveriam apontar qual dos sacramentos que o morto teria recebido.

Naturalmente, para saber se os defuntos "falecidos da vida presente" haviam ou não recebido os sacramentos no decorrer da existência, os padres teriam que recorrer aos livros de batizados, de matrimônios, das crismas e assim por diante. Assim, todo o registro paroquial servia também como fonte de consulta arquivística sobre as populações, o que corrobora a iniciativa adotada pela Igreja em tentar exercer controle sobre a vida social, a partir da memória que construía e preservava. Como afirmou Antonio Viñao Frago (1996), a escrita esteve ligada diretamente ao exercício do poder, sobretudo na época moderna.

O mesmo autor chama atenção à importância que o escrito adquiriu enquanto um testemunho; algo que ajudava à administração na elaboração de estratégias de poder baseadas em evidências escritas. A escrita, nas palavras de Viñao Frago, ajudava a "fossilizar o tempo". Em relação à administração eclesiástica, a exigência dos sacramentos como pré-requisitos à boa fé católica, produzia como consequência a escrita das certidões comprobatórias das cerimônias sacramentais. Tais ritos foram "fossilizados" no tempo através da escrita dos padres e, assim, evitando a perda da memória. A escrita das cerimônias, acompanhada pela assinatura do clérigo que a redigiu dava a legitimidade necessária ao escrito, evidentemente, conferida pela autoridade atribuída ao padre.

Não era, contudo, apenas o cargo de pároco que estabelecia autoridade aos religiosos. Ao assinar as certidões de batizado, matrimônio, entre outras, os clérigos prestavam seu testemunho de verdade o qual também era exigido de acordo com as Constituições Primeiras. Não se trata de um testemunho pessoal como aquele encontrado por James Amelang (2003) nas memórias de Miguel Parets, um artesão espanhol do século XVII.O personagem em questão se utilizou de textos diversos e conhecidos os quais ajudavam a compor seu testemunho em relação a acontecimentos

${ }^{9}$ ACMPOA. Porto Alegre. Pastorais. Livro II, p. 48. 
de sua época. ${ }^{10}$ Os padres, no entanto, conferiam testemunho como clérigos encarregados da administração e profissão da fé católica. Assinar os livros e suas respectivas certidões significava que o sacramento teria sido realizado, fosse por algum padre, ou outro leigo. A certidão assinada, contudo, era um testemunho de verdade em relação à efetividade dos sacramentos.

Alguns indícios apontam que as certidões tinham sua origem em cerimoniais públicos como as missas. Uma pequena amostragem elaborada a partir de uma série de batizados realizados no Acampamento do Rio Pardo (1755-1762) indica que, possivelmente, os batizados ocorriam junto às missas, principalmente naquelas feitas aos domingos. Dos 283 batizados de índios guaranis, 133 (47\%) ocorreram aos domingos, juntamente com mais 61 (30\%) de crianças da condição social branca. Embora, os dados em relação aos domingos chame bastante atenção, os dias da semana subsequentes apresentaram certo equilíbrio e regularidade na execução dos batizados. Assim, podemos supor que os batizados possivelmente ocorriam nas missas diárias em Rio Pardo, mas com a concentração aos domingos.

As certidões sacramentais, neste sentido, tais como a do batismo, poderiam gerar efeito de testemunho escrito sobre a realização das missas. Pelas determinações do Arcebispado da Bahia (1707), há a obrigatoriedade dos padres de celebrar as missas dominicais. O horário determinado para o culto era o matutino "desde que rompe a alva até o meio dia" (DA VIDE, 1707, Livro Segundo, Título IV, §336). A recomendação valia para todos os dias da semana. Mas era o domingo, no entanto, o dia obrigatório em que os padres deveriam celebrar missa:

Segundo Da Vide (1707): Conformando-nos com o costume geral, mandamos a nossos súditos, que ouçam Missa Conventual nos domingos, e dias Santos de guarda na Igreja Paroquial onde forem fregueses, e a ela façam ir seus filhos, criados e escravos, e todas as mais pessoas que tiverem a seu cargo, salvo aqueles que precisamente forem necessários para o serviço, e guarda de suas casas, gados, e fazendas, mas estes revezarão, para que não fiquem uns sempre sem ouvir Missa, antes vão ouvi-las uns em um dia, outros em outro [...].(DA VIDE, 1707, Livro Segundo, Título IV, §336)

A missa enquanto rito católico era o momento no qual se recriava a morte e paixão de Cristo. Simbolicamente, a morte representada no ofertório, durante a divisão da hóstia, expressava o momento mais sagrado do cristianismo, aos moldes católicos, quando se revivia o mito fundacional da própria religião. Junto à função espiritual, concorria o papel disciplinar dos comportamentos sociais. O tempo da missa e, sua

10Ver: AMELANG, James. El vuelo de Ícaro: la autobiografia popular en la Europa Moderna. Madrid: Siglo XXI, 2003. 
obrigatoriedade de execução aos domingos, contribuiu com o surgimento de uma política disciplinar da vida social. Como é possível observar nas Constituições Primeiras:

E para satisfazer a este preceito é obrigação abster de todo o trabalho, e obra servil, e mecânica, e autos judiciais, começando a guardar da meia noite, até a outra meia noite, e ocupando o dia em exercícios louváveis, fugindo dos pecados e ocasiões de os cometer, fazendo obras do serviço, gloria, e honra de Deus Nosso Senhor, e em louvor dos santos, em cuja memoria se manda guardar o dia.(DA VIDE, 1707, Livro Segundo, Título VII, §371)

O batismo, realizado no tempo das missas, também poderia funcionar como forma de disciplina. Seguindo tais indícios, demonstrados acima, podemos sugerir que o batismo tinha um alcance para além do sacramento. A presença dos pais, dos padrinhos e demais parentes e fregueses do Acampamento do Rio Pardo, por exemplo, ao ouvirem as missas, também recebiam a doutrina católica e a disciplina eclesiástica, necessária para a própria reprodução da religião. Mandar os filhos nas missas, escravos e demais pessoas, implica necessariamente numa tentativa da Igreja de se projetar sobre um vasto território de fronteira, onde se tentava homogeneizar comportamentos sociais em torno da religião.

\section{UM VISITADOR NA FRONTEIRA DA AMÉRICA MERIDIONAL}

O trabalho pastoral dos padres, como se sabe, era fiscalizado por outros religiosos visitadores, encarregados pelos bispados para verificar o estado das igrejas e a integridade das determinações dispostas nas Constituições Primeiras. Em Rio Pardo, o padre visitador Vicente José da Gama Leal, em 1782, primeiramente, fez elogios ao pároco encomendado. Na sequência de suas recomendações, no entanto, faz um alerta ao "pernicioso, diabólico e infernal abuso dos únicos divertimentos que ordinariamente sendo daquele se the ouve dar o difamante nome de fandango [...]". Segundo o visitador, nos fandangos ocorria o "erro e o vício do abuso dos bailes e das danças". ${ }^{11}$

O visitador ainda completou sua recomendação informando que "as danças promiscuas de homens e mulheres são como cruéis restos do paganismo". ${ }^{12}$ Ou seja, os restos do paganismo eram verdadeiros empecilhos à Igreja, pois eram práticas sociais que se davam fora da norma eclesiástica e há muito mais tempo. As queixas do visitador foram claras em respeito à preferência pelas festas de fandango por parte dos

${ }^{11}$ ACMPOA. Rio Pardo. Capítulos de Visitações, p. 4.

${ }^{12}$ ACMPOA. Rio Pardo. Capítulos de Visitações, 1782, p. 3v. 
homens e mulheres de Rio Pardo que, ao invés de praticarem as obras e os louvores a Deus, escolhiam os bailes de fandango.

Nos poucos dias de preceito que Deus reservou para seu culto se mostram os moradores desta Freguesia tão difíceis em se absterem de trabalhar negando com uma ingratidão esta pequena parte de tempo que para si tomou, ocupando-se em todas as obras servir nos domingos e dias de festas e com grande sentimento dos temores nem ao preceito da Missa e nem ao jejum, abstinência da carne nos dias proibidos pela Igreja $\left[\ldots . .{ }^{13}\right.$

Para o visitador, o pecado geral em que viviam os moradores de Rio Pardo residia no fato de não frequentarem as missas regularmente por darem preferencia ao trabalho diário e às danças de fandango. Por tal razão, o visitador recomendava:

Junte seu rebanho nos domingos e dias de festa para a Missa Paroquial, vestirá sua cota e pondo sua estola, principiará o terço de Nossa Senhoraem cuja recitação se deve empenhar e a animar seu Povo para que frequentem uma devoção que tanto cede em honra e agrado da Mãe de Deus e Rainha dos Anjos Nossa Senhora: lendo o terço principiará o aspergir, continuará a procissão das almas a qual deve assistir todo o Povo acompanhando o pároco nestes tão dignos sufrágios que se costumam fazer em benefício das almas do fogo do purgatório e imediatamente depois subirá ao púlpito, lugar mais próprio para instruir e explicar a seu Povo as verdades da Religião. ${ }^{14}$

Podemos notar que a Igreja fez da escrita um meio para evangelizar as populações coloniais. Os livros das visitações possibilitavam a formação de uma memória arquivística acerca do que deveria ser melhorado em termos de administração eclesiástica. O combate às práticas sociais indesejáveis pela Igreja nos coloca à frente de um momento histórico no qual ainda persistiam comportamentos sociais, identificados como práticas pagãs; "os restos do paganismo". Boa parte dos sistemas culturais em Rio Pardo, provavelmente, seguiam orientações valorativas diferentes das exigências eclesiásticas, obrigando o visitador a reconhecê-las como problemas à efetividade da disciplina eclesiástica a ser alcançada.

Os padres, porém, poderiam se utilizar dos termos de abertura dos livros batismais para repassar aos demais religiosos advertências acerca do trabalho evangelizador. No primeiro livro dos batizados de guaranis feito em Rio Pardo, no de 1758, pelo padre jesuíta Francisco Bernardes, encontra-se a seguinte descrição:

${ }^{13}$ Idem, p. 3v.

${ }^{14}$ Idem, p. 4. Grifos nossos. 
Para evitar de todo o inconveniente que na administração dos sacramentos podem os R.R. Párocos dos índios encontrar a diante vendo que os nomes que dão os índios não são os mesmos que se encontram nos assentos destes livros, no de casamentos parece [ilegível] preciso advertir que alguns índios guaranis que foram das Missões do Uruguai pela qualidade dos gênios amigos de novidades, ou por outro qualquer fim, que hei [ilegível] sua ministra a sua justiça capacidade, costumam mudar os nomes apelidando-se com outros que não celebram o batismo. $[\ldots]^{15}$

No final da advertência, Francisco Bernardes, se refere à prática indígena como um "rustico costume". É notável a necessidade dos padres conhecerem previamente seus fregueses na hora de administrar os sacramentos. Contudo, ao pensarmos num mundo de fronteira como a América Meridional, onde se achava o Acampamento do Rio Pardo, os constantes fluxos migratórios de populações tão diversas, certamente, a mobilidade populacional gerava grande empecilho aos padres em conhecer a realidade sociocultural de seus fregueses.

Assim sendo, se a interpretação de que os batizados eram realizados no intercurso das missas estiver correta, podemos acreditar que, através dele, a ação evangelizadora poderia alcançar maior vulto, não apenas pelo rito, mas também pela pregação oralizada desenvolvida pelos padres durante a missa. Aliás, o momento do batismo poderia dar aos clérigos a oportunidade certa para evangelizar os índios. Ao levarem seus filhos ao batismo, possivelmente os padres poderiam aproveitar o momento para concentrar esforços para divulgar a religião e os mandamentos da Santa Sé.

Nas últimas décadas trabalhos de diferentes áreas de conhecimento tem demonstrado interesse pelo estudo da oralidade. Essas pesquisas tem procurado identificar a palavra oral por detrás da representação escrita, ou seja, onde a dimensão histórica é primordial para o entendimento da oralidade enquanto aspecto indicativo da possibilidade de comunicação social e mesmo de cognição pessoal. ${ }^{16}$ Segundo as proposições de Paul Zumthor (1993, p. 142), o "trânsito vocal" era o único modo possível de socialização dos textos nos séculos XIII e XIV, sendo as relações entre a voz e a memória a única fonte de saber.

\footnotetext{
15 ACMPOA. Livros de Batismos. Rio Pardo (1758-1762). Termo de Abertura. Livro I dos Índios.

16 Para uma aproximação a outras formas de expressões na América colonial, ver: MASERA, Marina (cord.). La otra Nueva España: la palabra marginada en la Colonia. Barcelona: Editora Azul, 2002. Na América Portuguesa, mencionamos as pesquisasde João Adolfo Hansen, no caso a Bahia do século XVII, e as práticas letradas de Andréa Daher.Ver: HANSEN, João Adolfo. A sátira e o engenho. 2. ed. rev. São Paulo: Ateliê Editorial; Campinas: Ed. da Unicamp, 2004; DAHER, Andréa. A oralidade perdida: ensaios de história das práticas letradas. Rio de Janeiro: Civilização Brasileira, 2012.
} 
Assim, a oralidade assumia papel de destaque na tarefa religiosa. Conforme João Adolfo Hansen (2000), o modo de evangelização adotado pela Igreja Católica baseava-se na transmissão oral das sagradas escrituras. A pregação oral também foi escolhida no combate ao chamado gentilismo, visando favorecer a conversão dos índios do Brasil ao catolicismo. Evidentemente, em sociedades sem escrita, a oralidade possuía dimensões políticas e sociais diferenciadas das sociedades praticantes da palavra escrita.

Nesse aspecto, poderíamos supor que em Rio Pardo do século XVIII, havia uma mescla entre oralidade primária e oralidade mista. A primeira porque havia entre a população grupos ágrafos, os quais não transformavam a palavra falada em palavra escrita, como africanos e índios. A segunda, porque entre os europeus e alguns índios guaranis, a escrita era conhecida, embora seja difícil de medir o quanto a praticavam e o quanto transformavam a voz em letras.

No caso da Igreja, podemos pensar que sua ação disciplinar desenvolvida no Antigo Regime português, se dava em maior grau pela oralidade mista. Os evangelhos, a leitura das escrituras, sermões e pregações sacerdotais, em boa medida, pertenciam ao mundo da oralidade que no decorrer do tempo se transformaram em palavra escrita depositadas na Bíblia, nos manuais litúrgicos e no livro do Ritual Romano utilizados pela Igreja. Assim, observamos que uma tradição oral de longa data era possivelmente reproduzida nas missas na capela do Rio Pardo.

A preferência majoritária pelo domingo como dia para batizar, poderia dar à Igreja uma oportunidade única à evangelização, o que é perceptível na recomendação do visitador ao pároco de Rio Pardo para "subir ao púlpito, lugar mais próprio para instruir e explicar a seu Povo as verdades da Religião". Desse modo, era possível aos padres elaborar uma oratória deliberativa a qual segundo Hansen (2003, p. 5), "exortava os ouvintes a tomarem determinada atitude e para isso, argumentava sobre determinada questão, tentando persuadi-los da validade e conveniência de escolherem uma entre duas ou mais possibilidades de ação". ${ }^{17}$

A oratória foi uma ferramenta pedagógica importante à Igreja no trabalho de evangelização. Walter Ong (1998), aponta que a oralidade remete obrigatoriamente ao ato de comunicação. Assim, temos que o ato de se comunicar requer necessariamente dois sujeitos: o orador e o ouvinte. Em culturas de tradição oral, de acordo com autor, é o orador quem estimula o pensamento no ouvinte e este processo está intimamente ligado com a memória. Provocar o pensamento na tradição oral requer a combinação

17 A paginação mencionada foi feita pela contagem das folhas fotocopiadas, pois nelas não há número de página. 
de fórmulas e ritmos, capazes de ordenar o raciocínio e compor uma "verdade" sobre a vida social.

O esforço da Igreja Católica, neste sentido, era de moralizar a sociedade através de um discurso rítmico e cheio de fórmulas em que os padres deveriam ensinar "as verdades da religião". As recomendações do visitador Vicente José da Gama Leal ao pároco de Rio Pardo o incentivando principiar "o terço de Nossa Senhora em cuja recitação se deve empenhar e a animar seu Povo", passava pela díade fórmula - ritmo. A fórmula era o terço; um conjunto de orações distribuídas entre Ave Maria, Pai Nosso, entre outras, as quais eram repetidas inúmeras vezes. Através desta repetição seria possível memorizar os mistérios da religião, monopolizados e codificados pelos padres (oradores) e transmitidos ao Povo (ouvintes).

Uma das formas de divulgação dos mistérios da religião, sem dúvida, se dava através da recitação das orações de forma rítmica, capaz de "animar o Povo". A tentativa de evangelização pela oralidade poderia ser capaz de produzir no sistema cognitivo dos moradores de Rio Pardo, respostas rápidas, curtas e de fácil memorização. Talvez tenha sido esta a base de toda a estratégia adotada pela Igreja para evangelizar Rio Pardo, visto que o alcance da palavra falada, certamente, contava com maior amplitude social, em termos de propagação, do que a palavra escrita.

Neste aspecto, o combate ao "império do demônio", exigido pelo visitador Vicente José da Gama Leal, passava obrigatoriamente pela tradição oral e garantia aos clérigos a legitimação sociológica de suas funções. A evangelização, contudo, se apoiava tanto na oralidade quanto na palavra escrita. Seja como for, não podemos compreender, no entanto, que escrita e oralidade fossem contraditórias naquele contexto. A Igreja Católica utilizou estas duas formas de oralidade de forma combinada no trabalho evangelizador. Tanto no processo escriturário das certidões sacramentais como também na pregação feita nas missas.

O processo escriturário do batismo, por exemplo, envolvia um complexo processo de transformação da palavra falada em palavra escrita, o que era previsto pelas Constituições Primeiras do Arcebispado da Bahia. Para redigir as certidões batismais, era exigido aos padres, segundo Constituições Primeiras que:

[...] se informará (não lhe constando) se é de sua Paróquia, se foi batizado em casa, por quem, e em que forma, quem há de ser o padrinho, e madrinha, e do nome que há de ter a criança: [...] pronunciando as palavras da forma do batismo, meterá a criança na água com a boca para baixo uma só vez pelo perigo que pode haver sendo três as imersões.(DA VIDE, 1707, Livro I, Título XII, §41).

Podemos observar no trecho acima que, a indagação aos pais das crianças batizadas fazia parte do processo escriturário do assento batismal. Podemos contrastar 
estes indícios com o que a mesma Igreja Católica sugeria quanto ao modo usual de se fazer o registro batismal, previsto nas Constituições Primeiras:

Aos tantos de tal mês, e de tal ano batizei, ou batizou parte de minha licença o Padre $\mathrm{N}$, nesta ou em tal Igreja a $N$, filho de $N, e$ de sua mulher $N$. e lhe pus os santos óleos: foram padrinhos $\mathrm{N}$. e N. casados, viúvos ou solteiros, fregueses de tal Igreja, e moradores em tal parte.(Grifos nossos).(DA VIDE, 1707, Livro I, Título XX, 70)

Assim, temos que o nome da criança, o nome dos genitores, suas respectivas naturalidades e o nome dos padrinhos eram declarações que deveriam ser prestadas pelos fregueses no momento do batismo, o que na prática ocorria na maior parte dos batizados. Além das informações que deveriam ser tomadas junto aos pais das crianças, o rito católico também era um momento em que a oralidade ajudava a dar sentido ao próprio ritual. Segundo as determinações prescritas pelas Constituições baianas o sacramento do batismo necessitava de três elementos: matéria, forma e ministro para que tivessem legítima validade.

Com isso, além dos padres se utilizarem de uma forma estética usual na composição das certidões batismais, outra parte importante na materialização destes escritos se dava através de um processo dialógico entre padres e Povo. Além disso, a entrada ao catolicismo via batismo se fazia pela pronúncia de "palavras mágicas", uma fórmula geral: eu te batizo em nome do Pai e do Filho e do Espirito Santo. Ou seja, a Igreja usava de forma combinada a oralidade e a escrita para ordenar socialmente as populações do Brasil colonial.

\section{CONSIDERAÇÕES FINAIS}

Neste artigo, tentou-se apresentar algumas notas sobre as formas de evangelização desenvolvidas pela Igreja Católica numa região fronteiriça do Brasil colonial. Neste processo observa-se que a Igreja usou dois tipos de linguagens combinadas para divulgar e propagar o catolicismo; a linguagem escrita e a falada. Em relação à escrita, primeiramente, cabe destacar que sua importância à atividade eclesiástica, assumia papel ordenador em relação ao mundo social. Os processos escriturários envolvidos na produção das certidões de batismo são exemplares neste sentido.

As certidões tinham sua origem material dada pela realização do sacramento. Nelas, os padres assinavam dando assim a legitimidade necessária para que fossem reconhecidas como verdadeiras, além de garantirem que os sacramentos foram devidamente realizados. Depois que eram feitas, e assentadas em livros, as certidões 
batismais poderiam ser usadas de forma arquivística pela Igreja para obter informações da população visando algum tipo de controle social. Para se casar em matrimônio, por exemplo, homens e mulheres deveriam ser obrigatoriamente batizados. $O$ batismo era pré-requisito não só para o matrimônio, como também à crisma.

Assim, por meio dos arquivos eclesiásticos, a Igreja poderia exercer seu poder estabelecendo certo controle social, onde seria possível obter informações sobre o Povo. Os arquivos poderiam dar oportunidade à Igreja de monitorar as populações, enquadro-as, dentro do possível, aos preceitos da religião católica. Os arquivos poderiam servir a elaboração de um tipo de memória administrativa a qual daria suporte às atividades pastorais. A escrita arquivística ajudaria a criar um conjunto de informações sobre um determinado acontecimento o qual poderia ser usado num futuro incerto. As recomendações pastorais dos padres visitadores podem servir de exemplo.

Por fim, a oralidade foi outro suporte importante no trabalho evangelizador desenvolvido pela Igreja Católica. Como foi demonstrado, os moradores de Rio Pardo, segundo o visitador, eram resistentes a algumas exigências eclesiásticas. Entre elas, o comparecimento obrigatório nas missas dominicais. Contudo, mesmo assim, foram os domingos os dias em que mais ocorreram batizados. Articulando tais indícios, podemos acreditar que estes batizados se davam nas missas dominicais. Desse modo, a Igreja poderia ter uma boa oportunidade em pregar os valores das sagradas escrituras às populações. Os padres poderiam dessa forma, exprimir através da oralidade os valores morais da religião, apontando qual seria o caminho mais virtuoso à vida social.

\section{REFERÊNCIAS}

AMELANG, James. El vuelvo de Ícaro: la autobiografia popular en la Europa Moderna. Madrid: Siglo XXI, 2003.

BOUZA, Fernando. Del escribano a la biblioteca: lacivilización escrita europea en la Alta Edad Moderna (siglos XV-XVII). Madrid: Síntesis, 1992.

DAHER, Andréa. A oralidade perdida: ensaios de história das práticas letradas. Rio de Janeiro: Civilização Brasileira, 2012.

DA VIDE, Sebastião Monteiro. Constituições Primeiras do Arcebispado da Bahia. Coimbra: Colégio das Artes da Companhia de Jesus, 1707.

GÓMEZ, Antonio Castillo. La fortuna de lo escrito: funciones y espacios de larazón gráfica (siglos XV-XVII). Bulletin Hispanique, Bordeaux, t. 100, n. 2, p. 803-829,1998. 
HANSEN, João Adolfo. A civilização pela palavra. In: LOPES, Eliane M.T; FILHO, Luciano, M.F; VEIGA, Cynthia G. (org). 500 anos de educação no Brasil. Belo Horizonte: Autêntica, 2000.

HANSEN, João Adolfo. A sátira e o engenho. 2. ed. rev. São Paulo: Ateliê Editorial; Campinas: Ed. da Unicamp, 2004.

KÜHN, Fabio. O projeto reformador da Diocese do Rio de Janeiro: as visitas pastorais no Rio Grande de São Pedro (1780-1815). 1996. Dissertação (Mestrado em História). Instituto de Filosofia e Ciências Humanas. Universidade Federal do Rio Grande do Sul, Porto Alegre, 1996. MASERA, Marina (coord.). La otra Nueva España: la palabra marginada en la Colonia. Barcelona: Azul, 2002.

MELO, Karina Moreira Ribeiro da Silva e. A aldeia de São Nicolau do Rio Pardo: histórias vividas por índios guaranis (séculos XVIII-XIX). 2011. Dissertação (Mestrado em História) - Programa de Pós-Graduação em História. Instituto de Filosofia e Ciências Humanas. Universidade Federal do Rio Grande do Sul, Porto Alegre, 2011.

ONG, Walter. Oralidade e cultura escrita: a tecnologia da palavra. Campinas: Papirus, 1998.

VIÑAO FRAGO, Antonio. Por una historia de cultura escrita: observaciones y reflexiones.

SIGNO. Revista de la Cultura Escrita. Universidad de Alcalá de Henares, [Alcalá de Henares],n.3, p.41-68, 1996.

ZUMTHOR, Paul. A letra e a voz: literatura medieval. São Paulo: Companhia das Letras, 1993. 